Volume VII - Article Four

\title{
WOULD YOU LIKE THAT IPHONE LOCKED OR UNLOCKED?: RECONCILING APPLE'S ANTICIRCUMVENTION MEASURES WiTH THE DMCA
}

\author{
Daniel J. Corbett ${ }^{1}$
}

Spring 2008

\section{Copyright (C) University of Pittsburgh School of Law \\ Journal of Technology Law and Policy}

\footnotetext{
${ }^{1}$ University of Pittsburgh School of Law, J.D. expected 2009. I would like to thank my fiancée, Erin, my family, and my friends for asking thoughtful questions and providing me with support and understanding throughout this process. I would also like to thank Professor Michael Madison for his insights and suggestions regarding various points of copyright law. Lastly, I would like to thank my mentor, Mark Johnson, for his help in editing this Note.
} 


\section{Table of Contents}

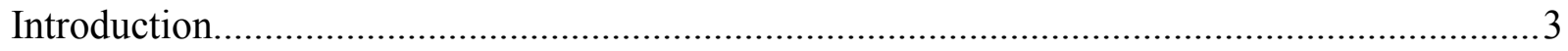

I. THE DMCA AND ANTICIRCUMVENTION TECHNOLOGIES...................................... 5

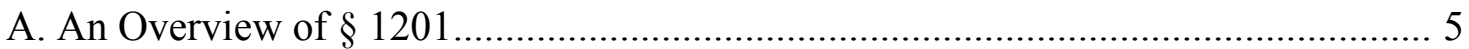

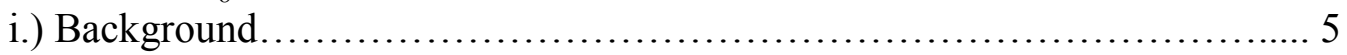

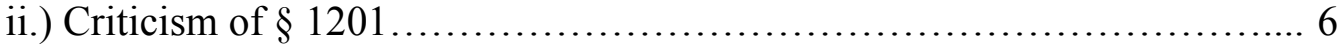

B. Possible Antitrust Arguments............................................. 7

C. Amending the DMCA Anticircumvention Provisions: The $\S 1201$ Rulemaking

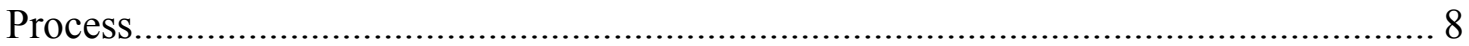

i.) Background and Overview.................................................................... 8

ii.) The Necessary Showing......................................................................... 9

D. The 2006 Rulemaking Exemptions to § 1201 ........................................................ 10

E. Policy Justifications for the Mobile Phone Exemption............................................... 10

III. Application of the Mobile Phone Exemption to Apple's Conduct......................................... 12

A. Apple's Arguments Supporting its use of Anticircumvention Technologies.............. 13

i.) iPhone Users Who Unlocked Their Phones Violated Their Contracts with

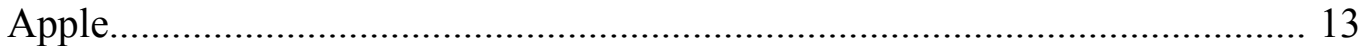

ii.) The DMCA Exemption Has Been Weakened by Tracfone............................. 15

B. Arguments Against Apple's Use of Anticircumvention Technologies........................16

i.) The iPhone Contracts May Be Preempted by Copyright Law......................... 16

ii.) The iPhone Contracts May be Unenforceable as a Matter of Public Policy.. 17

(a) Framing Consumers' Policy Argument.............................................. 18

(b) Evaluating Consumers' Policy Argument in Light of Existing

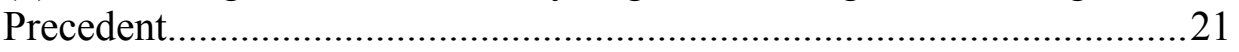

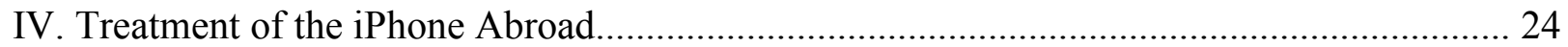

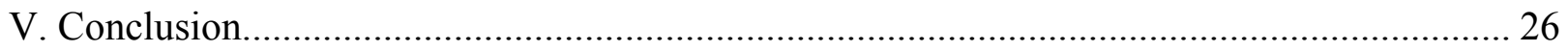




\section{Introduction}

When Apple's iPhone first hit the stores it was an epochal media event. ${ }^{2}$ Apple, long a leader in high-end computers and personal electronics, was poised to make its entry into a highly-competitive market with a new mobile phone that promised groundbreaking technological capabilities in a sleek, ergonomic package. Apple's CEO, Steve Jobs, extolled the iPhone's virtues to an eager press, and, shortly thereafter, Apple's stock jumped dramatically. ${ }^{3}$ Apple's loyal devotees lined up in anticipation days before the phone's June 29, 2007 release. ${ }^{4}$ It took Apple a mere seventy-four days to sell one million handsets. ${ }^{5}$ But some time after the fanfare had settled down, public perception of the iPhone shifted. As consumers began to use the iPhone, the once-beloved phone began to acquire its share of discontents. Consumers expressed frustration in response to 300 -page phone bills, ${ }^{6}$ expensive roaming charges, ${ }^{7}$ and, perhaps most vocally, to the technological methods Apple used to police its exclusive agreement with AT\&T. ${ }^{8}$

Apple entered into an agreement with AT\&T under which AT\&T agreed to provide exclusive service for the iPhone. ${ }^{9}$ Pursuant to this agreement, Apple engineered its handsets to prevent consumers from accessing other wireless networks and installing third-party software. ${ }^{10}$

It took consumers little time to undercut Apple's anticircumvention efforts and 'unlock' the

\footnotetext{
${ }^{2}$ See, e.g., Declan McCullagh, Update: iPhone Will Be Released on June 29, CNET NEws.COM, Mar. 29, 2007, http://www.news.com/8301-10784_3-6171953-7.html.

${ }^{3}$ Owen Thomas, Apple: Hello, iPhone, CNN MONEY.COM, Jan. 9, 2007, http://money.cnn.com/2007/01/09/technology/apple_jobs/index.htm.

${ }^{4}$ Anick Jesdanun, Customers Line Up for Apple's iPhone Days Before Friday's Launch, SF GATE, June 26, 2007, http://www.sfgate.com/cgi-bin/article.cgi?f=/n/a/2007/06/26/financial/f153355D88.DTL.

${ }^{5}$ Jonathan Skillings, Apple: 1 Million iPhones Sold, CNET News.COM. Sept. 10, 2007. http://www.news.com/830110784_3-9774593-7.html.

${ }^{6}$ Gregg Keizer, A 300-page iPhone Bill?, PC WorLd, Aug. 16, 2007, http://www.pcworld.com/article/id,136068/article.html.

${ }^{7}$ Katie Hafner, Roaming iPhone Fees Can Be a Huge Shock, International Herald Tribune, Sept. 10, 2007, http://www.iht.com/articles/2007/09/10/news/iphone10.php.

${ }^{8}$ Code to Unlock iPhone Cracked, CNN.COM, Sept. 1, 2007, http://edition.cnn.com/2007/TECH/09/01/apple.iphone/.

${ }^{9}$ Id.

${ }^{10} I d$.
} 
iPhone. ${ }^{11}$ Apple responded quickly and forcefully, using its automated software update system to render inoperable all handsets that had been unlocked. ${ }^{12}$ (Or, to put it in techie lexicon, Apple 'bricked' any unlocked iPhones. ${ }^{13}$ ) Apple's actions have engendered animosity among onceloyal customers, inspiring a consumer "rebellion" that began among the technological elite and spread across the consuming public. ${ }^{14}$ One good indication that this rebellion reached a critical mass is the fact that, as of January 2008, an estimated 1.7 million iPhones had been unlocked. ${ }^{15}$ News of this large number of unlocked phones may have been a contributing factor to a recent plunge in Apple's stock price per share. ${ }^{16}$ Eventually, this consumer dissatisfaction led to a class action brought by a group of iPhone owners. ${ }^{17}$

This Note examines the legal issues surrounding Apple's use of anticircumvention technology in connection with its iPhone as it relates to copyright law. ${ }^{18}$ Part II discusses an exemption to the Digital Millennium Copyright Act (DMCA) that allows mobile phone users to unlock their phones to lawfully access third-party networks. Part III examines how this exemption applies to Apple's recent locking of iPhones and argues that, in light of the policies supporting the exemption, this exemption should prohibit Apple's conduct. Part IV looks at the way the iPhone is treated in countries outside the United States with respect to exclusive deals

\footnotetext{
${ }^{11} I d$.

${ }^{12}$ Katie Hafner, Altered iPhones Freeze Up, N.Y. Times, Sept. 29, 2007, at C1.

${ }^{13}$ A "brick" describes an electronic device that does not function in any capacity. For a fairly thorough etymology of the term "brick," see Brick (electronics), WIKIPEDIA, http://en.wikipedia.org/wiki/Brick_\%28electronics\%29 (last visited February 19, 2008).

${ }^{14}$ Laura M. Holson, Cellphone Straitjacket Is Inspiring a Rebellion, N.Y. TIMES, Nov. 12, 2007, at C1.

15 Olga Kharif and Peter Burrows, Millions of iPhones Go AWOL, Business WeEK, Jan. 28, 2008, http://www.businessweek.com/technology/content/jan2008/tc20080128_984623.htm reference to this particular suit. See David Chartier, California Man Seeks Class Action Lawsuit Over iPhone Bricking, Lock-in, ARS TECHNICA, Oct. 7, 2007, http://arstechnica.com/news.ars/post/20071007-california-manseeks-class-action-lawsuit-over-iphone-bricking-lock-in.html.

${ }^{18}$ This note focuses on the legal and policy implications surrounding the iPhone's apparent conflict with a particular rulemaking exemption to the Digital Millennium Copyright Act. Although there is clearly an interesting antitrust discussion to be had, and although the aforementioned pending class action lawsuit focuses primarily on antitrust violations, the focus of this paper will nonetheless be copyright law. See infra Part II.A.3.
} 
with wireless providers. It suggests that France's treatment of the iPhone (offering both "locked" and "unlocked" models) marks the most sensible approach, and that consumers in the United States would be benefited by such an approach. Part V recaps the relevant law and policy concerns and suggests some potential approaches in solving the dilemmas facing both Apple and the consuming public.

\section{The DMCA and Anticircumvention Technologies}

\section{A. An Overview of $\S 1201$}

\section{i.) Background}

Digital technology presents numerous opportunities for producers of copyrighted works, giving them a mechanism for efficient, global distribution at a marginal price. Although these technologies enhance the distributional capabilities of producers, they simultaneously enable consumers to more readily infringe copyrights. ${ }^{19}$ To prevent infringement, copyright holders employ both technical and legal methods of protection. ${ }^{20}$ One technological tactic copyright holders use is to encrypt content before delivery and allow consumers access through passwords and codes. ${ }^{21}$ But encryption methods are rarely impervious and 'hackers' often find ways around such technological protections. ${ }^{22}$

In 1998, Congress enacted $\S 1201$ of the Digital Millennium Copyright Act (DMCA), which, among other things, provides a legal backing for these technological protections as means of providing content owners stronger protection for their copyrighted materials. ${ }^{23}$ Under $\S 1201$

\footnotetext{
${ }^{19}$ It should be noted that, because the subject matter of copyright (see 17 U.S.C. $\S 102$ ) has been read to include computer software, copyright infringement is now possible in a wide range of different contexts. Infringement may occur any time that someone modifies or manipulates any form of software or computer code protected under the Copyright Act.

${ }^{20}$ Marcus Howell, The Misapplication of the DMCA to the Aftermarket, 11 B.U. J. SCI. \& TECH. L. 128, 129-30 (2005).

${ }^{21} I d$.

${ }^{22} \mathrm{Id}$.

${ }^{23} \mathrm{Id}$.
} 
of the DMCA, the circumvention of technological controls on a copyrighted work is a distinct, cognizable form of infringement. ${ }^{24}$ In particular, the section provides, in part, that "No person shall circumvent a technological measure that effectively controls access to a work protected under this title."25

\section{ii.) Criticism of $\S 1201$}

The DMCA's anticircumvention provisions face criticism on a number of grounds. Some commentators note that these provisions offend some of the basic policies underlying copyright law and, more generally, intellectual property law. ${ }^{26}$ The Congressional intent behind our intellectual property laws is quite clear. The laws exist "[ $\mathrm{t}]$ o promote the Progress of Science and useful Arts." ${ }^{, 27}$ Because copyright and patent each confer a species of monopoly status to the creator or inventor of a particular work or invention, Congress was careful to build in certain internal limitations to intellectual property law. The rights conferred to owners of intellectual property do not exist in perpetuity, but rather only "secure[s] for limited Times to Authors and Inventors the exclusive Right to their respective Writings and Discoveries."28 This narrow, limited set of powers for intellectual property law which Congress had in mind seems to be in conflict with some potential applications of $\S 1201$ of the DMCA.

Indeed, critics of the DMCA have argued that the anticircumvention provisions are not grounded on general copyright principles of rewarding original works of authorship, as much as they are grounded on the ambition of original goods manufacturers to prevent aftermarket

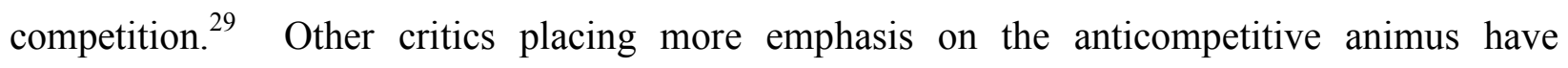

\footnotetext{
${ }^{24} 17$ U.S.C. $\S 1201$ (2006).

2517 U.S.C. $\$ 1201(\mathrm{a})(1)(\mathrm{A})(2006)$.

${ }^{26}$ Howell, supra note 20, 136-37.

${ }^{27}$ U.S. CONST. art. $1, \S 8$, cl. 8 .

${ }^{28} I d$.

${ }^{29}$ Howell, supra note 20, at 138.
} 
suggested that the DMCA's anticircumvention provisions may run afoul of antitrust law. ${ }^{30}$ Regardless of how the critique is framed, it is clear that $\S 1201$, as written, is rife with the potential to be applied in an overly-broad, anticompetitive manner, which would appear to stand in stark opposition to the fundamental aims of copyright law.

\section{B. Possible Antitrust Arguments}

So if antitrust claims might possibly address some of these concerns, why should we seek to change the copyright law? The answer is fairly straightforward and has to do with the basic architecture of antitrust law. Antitrust law, particularly in recent years, has recognized the possibility that some limits on competition may be desirable to the extent that they lead to greater efficiency, thus creating an aggregate societal benefit. ${ }^{31}$ Thus, rather than banning certain anticompetitive arrangements as per se illegal, courts will often consider whether the anticompetitive behavior is a reasonable means of achieving certain business goals. ${ }^{32}$ Indeed, since the 1980s, antitrust has been evolving to incorporate a more flexible, efficiency-oriented analysis when dealing with problems relating to technology and intellectual property. ${ }^{33}$ One might still try to fit certain DMCA problems - particularly the problem at hand regarding the iPhone-within antitrust law by arguing that such behavior constitutes improper tying of a product and a service. $^{34}$ While this is an appealing legal theory, it should be noted that this

\footnotetext{
${ }^{30}$ Lance C. McCardle, Comment, Despite Congress's Good Intentions, the DMCA's Anti-Circumvention Provisions Produce a Bad Result - A Means to Create Monopolies, 50 LoY. L. REV. 997, 998-99 (2004).

${ }^{31}$ Putting a primacy on economic efficiency, members of the "Chicago School" have generally dismissed antitrust's purported goal of avoiding monopoly profits and the transfer of wealth from consumers to producers. These scholars and judges have suggested that the proper focus of antitrust should be efficiency, both allocative and productive. Thus, restraints on competition will not always have negative effects and may, in fact, have certain salutary effects. See, e.g., Robert Bork, The Antitrust Paradox: A POlicy At War With ItSelf, at xi-xii (Basic Books 1993) (1978).

${ }^{32}$ See E. Thomas Sullivan and Herbert Hovenkamp, Antitrust Law, Policy and Procedure: Cases, MATERIALS, AND PROBLEMS, 23-25 (5th Ed. 2003). - must check content.

${ }^{33}$ Makan Delrahim, Maintaining Flexibility in Antitrust Analysis: Meeting the Challenge of Innovation in the Media and Entertainment Industries. 28 COLUM. J.L. \& ARTS 343, 347 (2005).

${ }^{34}$ In general, "tying" refers to "an agreement by a party to sell one product but only on the condition that the buyer also purchases a different (or tied) product, or at least agrees that he will not purchase that product from any other
} 
theory only applies when the firm accused of engaging in tying possesses "appreciable economic power." ${ }^{35}$ Given the malleable nature of antitrust law and the difficult standards it sometimes employs, it is unlikely that opponents of anticircumvention technologies will find much refuge in antitrust. Thus, the best way to address these concerns is by amending the DMCA itself.

\section{Amending the DMCA Anticircumvention Provisions: The $\$ 1201$ Rulemaking Process}

\section{i.) Background and Overview}

In response to the broad language and potentially broad application of $\S 1201(\mathrm{a})(1)(\mathrm{A})$, Congress wrote in a "fair use" exception in $\S 1201(\mathrm{a})(1)(\mathrm{B}) .{ }^{36}$ The policy goal here was similar to the policy goal for fair use $\mathrm{e}^{37}$ in general — to provide the public with clear rules that would allow them to know exactly when copyright has occurred and to allow certain "noninfringing uses" that are either beneficial to society or at least harmless to the copyright holder. ${ }^{38}$ Subparagraph (B) limits the application of $\S 1201$ so as not to apply to persons using a copyrighted work that falls within a particular class of works, "if such persons are, or are likely to be in the succeeding 3-year period, adversely affected by virtue of such prohibition in their ability to make noninfringing uses of that particular class of works." ${ }^{39}$ Pursuant to the DMCA, the Register of Copyrights carves out new exceptions to $\S 1201$ through a rulemaking process held every three years. ${ }^{40}$ The process is fairly straightforward: the Register of Copyrights is to notify the public of a period of public comment; after receiving public comments on proposed $\S$ 1201 exemptions during that period, the Register of Copyrights then consults with the Assistant

supplier.” Eastman Kodak Co. v. Image Technical Services, Inc., 504 U.S. 451, 461-62 (1992) (quoting Northern Pacific Railway Company v. United States, 356 U.S. 1, 5-6, (1958)).

${ }^{35}$ Id. at 462 (citing Fortner Enterprises, Inc. v. United States Steel Corp., 394 U.S. 495, 503 (1969)).

${ }^{36} 17$ U.S.C. $\S 1201(\mathrm{a})(1)(B)(2006)$.

${ }^{37} 17$ U.S.C.. $§ 107$ (2006).

${ }^{38}$ See, for example, Campbell v. Acuff-Rose Music, Inc., 510 U.S. 569 (1994); Harper \& Row v. Nation Enter., 471 U.S. 539 (1985), for a good general overview of the fair use doctrine.

${ }^{39} 17$ U.S.C.. $\$ 1201(\mathrm{a})(1)(\mathrm{B})$.

${ }^{40} 17$ U.S.C. $§ 1201(\mathrm{a})(1)(\mathrm{C})(2006)$. 
Secretary for Communications and Information of the Department of Commerce; then the Registrar of Copyrights makes final recommendations to the Librarian of Congress. ${ }^{41}$ According to the terms of the rulemaking procedure, these exemptions were to stay in effect for three years. ${ }^{42}$ For Congress, the rulemaking procedure cleared up all worries regarding $§ 1201$ 's broad language and, as the legislative history indicates, the procedure was considered something of a "fail-safe" mechanism. ${ }^{43}$ Whether or not the rulemaking procedure is, in fact, such a "fail-safe" mechanism is perhaps irrelevant. As a practical matter, the procedure is the only method of amending or modifying $\S 1201$ to meet the needs of the public. Thus, all proposed reforms to the DMCA's anticircumvention provisions must conform to the standards set forth in the rulemaking procedure. $^{44}$

\section{ii.) The Necessary Showing}

Pursuant to the rulemaking procedure, any proponent of an exemption to $\S 1201$ carries the burden of proof. ${ }^{45}$ Proponents of a new exemption must make a showing, by a preponderance of the evidence, that there "has been or is likely to be a substantial adverse effect on noninfringing uses by users of copyrighted works." ${ }^{, 46}$ Importantly, in the event that an exemption is successfully created, it does not create a presumption for the continued existence of

\footnotetext{
${ }^{41}$ Exemption to Prohibition on Circumvention of Copyright Protection Systems for Access Control Technologies, 71 FED. REg. 68,472-01 (Nov. 27, 2006) (to be codified at 37 C.F.R. pt. 201) [hereinafter Exemption to Prohibition on Circumvention.

${ }^{42} I d$.

${ }^{43} I d$.

${ }^{44}$ The statute sets out the following criteria which are to be used in making such determinations:

(i) the availability for use of copyrighted works;

(ii) the availability for use of works for nonprofit, archival, preservation, and educational purposes;

(iii) the impact that the prohibition on the circumvention of technological measures applied to copyrighted works has on criticism, comment, news reporting, teaching, scholarship, or research;

(iv) the effect of circumvention of technological measures on the market for or value of copyrighted works; and

(v) such other factors as the Librarian considers appropriate. 17 U.S.C. $\$ 1201(\mathrm{a})(1)(\mathrm{C})$.

${ }^{45}$ Laura Gasaway, Anticircumvention Ruling - Copyright Corner, INFORMATION OUTLOOK, Feb. 2004, $\mathrm{http} / / /$ findarticles.com/p/articles/mi_m0FWE/is_2_8/ai_114010242.

${ }^{46} I d$.
} 
that exemption. ${ }^{47}$ Instead, the proponent will be required to make another prima facie case once the three-year period has expired. ${ }^{48}$

\section{The 2006 Rulemaking Exemptions to $\$ 1201$}

In 2006, the Copyright Office issued a determination providing six new exemptions from the DMCA's anticircumvention provisions. ${ }^{49}$ Among other things, the 2006 Register of Copyrights concluded that use of the following technology would not constitute copyright infringement: "[c]omputer programs in the form of firmware that enable wireless telephone handsets to connect to a wireless telephone communication network, when circumvention is accomplished for the sole purpose of lawfully connecting to a wireless telephone communication network." ${ }^{50}$ The Register of Copyrights concluded that the software locks used by handset manufacturers "are access controls that adversely affect the ability of consumers to make noninfringing use of the software on their cellular phones." ${ }^{, 51}$ The creation of this exemption was particularly important because it carved out an important space within the DMCA, giving cell phone users clear expectations as to permissible uses of the handsets they purchased. In a way, the exemption can be seen as copyright law's way of acceding to a growing consumer demand to "free the cell phone!"52

\section{E. Policy Justifications for the Mobile Phone Exemption}

Leading up to the 2006 rulemaking, those in technological circles were becoming frustrated with anticircumvention technologies that prevented consumers from unlocking their

\footnotetext{
${ }^{47} I d$.

${ }^{48}$ For each successful exemption, the evidence must be represented every three years in order for it to continue. Id.

${ }^{49}$ Exemption to Prohibition on Circumvention, supra note 41.

${ }^{50} I d$.

${ }^{51} I d$.

52 Jennifer Granick, Free the Cell Phone!, WIRED, Sept. 28, 2005, http://www.wired.com/politics/law/commentary/circuitcourt/2005/09/68989.
} 
mobile phones to enable them to work on more than one network. ${ }^{53}$ Wireless companies were using software locks to prevent consumers from manipulating software embedded in the phone that would allow consumers to access to other networks. ${ }^{54}$ Section 1201(a) of the DMCA seemed to provide wireless companies with a way to prevent customers from using "unlocking" software to access the wireless network of their choice. ${ }^{55}$ In order to prevent handset manufacturers from using copyright as shield, public interest groups and private individuals banded together to file a public comment as part of the triennial DMCA rulemaking. ${ }^{56}$

The range of concerns raised by proponents of the exemption varied considerably. According to one comment filed as part of the public comment period, some of the dangers involved included: (1) a decrease in competition and consumer choice, which would, in turn, lead to poorer service and higher costs for customers; (2) an "environmental disaster as a result of mobile handset waste;" and (3) a widening of the "digital divide" between developed and developing nations. ${ }^{57}$ Although concerns about environmental waste and lack of technological access in the developing world were certainly on the table during the rulemaking process ${ }^{58}$, concerns over lack of consumer choice perhaps carried the day for proponents of the exemption, and will be the primary focus of this Note.

Although it is perhaps more commonly argued that anticircumvention technologies as applied to mobile phones will provide consumers with less choice, strong arguments on both sides can be leveled. Those who oppose the 2006 rulemaking exemption to the DMCA would likely argue that

\footnotetext{
${ }^{53}$ Press Release from Electronic Frontier Foundation, Trusted Computing Group Helps Lock Down Mobile Phones, (Sept. 29, 2005) available at http://www.eff.org/press/archives/2005/09/29.

${ }_{54}$ JONATHAN R. NEWMAN \& ROBERT PINKERTON,_NOTICE OF INQUIRY IN RE EXEMPTION TO PROHIBITION ON CIRCUMVENTION OF COPYRIGHT PROTECTION SYSTEMS FOR ACCESS CONTROL TECHNOLOGIES BEFORE THE LIBRARY OF CONGRESS COPYRIGHT OFFICE, http://www.copyright.gov/1201/2006/comments/granick_wirelessalliance.pdf.

${ }^{55} \mathrm{Id}$.

${ }^{56} \mathrm{Id}$.

${ }^{57} \mathrm{Id}$.

${ }^{58} \mathrm{Id}$.
} 
their use of anticircumvention technologies will inevitably lead to more consumer choice. ${ }^{59}$ This argument is predicated upon the notion that greater ability to control products will enhance profitability, thereby creating greater incentives for a wider range of firms to produce a wider range of products. ${ }^{60}$ On the other hand, those who support the exemption would likely argue that content owners' use of such measures actually depletes consumer choice because it allows for a small number of large firms to effectively take control of their respective markets. ${ }^{61}$ These problems, centering on market power and consumer choice, may very well sound like the purview of antitrust law. As mentioned earlier, for practical and doctrinal reasons, antitrust law is not well-equipped to handle these particular problems. ${ }^{62}$ At the very least, the DMCA's protection of anticircumvention technologies, in the context of the market for mobile phones, presented a clear problem because it offended the basic principles of copyright law, while at the same time raising concerns about lack of competition. This claim is supported by the express language of the Register of Copyrights:

[T] he access controls do not appear to actually be deployed in order to protect the interests of the copyright owner or the value or integrity of the copyrighted work; rather, they are used by wireless carriers to limit the ability of subscribers to switch to other carriers, a business decision that has nothing whatsoever to do with the interests protected by copyright. ${ }^{63}$

\section{Application of the Mobile Phone Exemption to Apple's Conduct}

In light of the preceding discussion of the DMCA and its 2006 exemptions, it is clear that copyright law generally protects consumers from DMCA liability when they unlock a mobile phone in order to lawfully access a different wireless network. ${ }^{64}$ This will remain the law until

\footnotetext{
${ }^{59}$ Jeremy F. deBeer, Locks \& Levies, 84 DENV. U. L. REV. 143, 171 (2006).

${ }^{60} \mathrm{Id}$.

${ }^{61} \mathrm{Id}$.

${ }^{62} \mathrm{Id}$.

${ }^{63}$ Exemption to Prohibition on Circumvention, supra note 41.

${ }^{64}$ See generally Id.
} 
October 27, 2009, when the exemption will be up for renewal, pursuant to the DMCA rulemaking procedure. ${ }^{65}$ The question is whether Apple, in taking steps to prevent its customers from unlocking their iPhones, has violated this copyright law provision. This implicates certain tensions between intellectual property and contract law. On one hand, proponents of the exemption can argue that it should be enforced here because it supports a more competitive market for mobile phones and greater consumer freedom, while at the same time upholding a limited, sensible approach to copyright law. On the other hand, Apple can argue that this is actually a matter of contract law, and that their customers have, quite simply, gotten what they signed up for-an iPhone with service provided exclusively by AT\&T. How do we reconcile these competing viewpoints? A fair treatment of this question will involve a balancing of the policy considerations that support the DMCA exemption and the economic considerations that support Apple's argument. This treatment will draw on these general policy/economic arguments and the case law, legislative history, and scholarship that support them.

\section{A. Apple's Arguments Supporting Its Use of Anticircumvention Technologies}

Apple has two basic arguments in defense of its conduct. Apple's strongest argument is relatively straight-forward: aggrieved consumers are not entitled to any relief because they have plainly violated the terms of their agreement with Apple. Apple may also cite TracFone, a recent case interpreting the 2006 DMCA exemption and limiting its application. ${ }^{66}$

\section{i.) iPhone Users Who Unlocked Their Phones Violated their Contracts with Apple}

Apple's chief argument would likely be that the DMCA exemption is irrelevant here in view of the contract between Apple and iPhone owners. Although AT\&T's role as sole carrier is central to this discussion, it is not the AT\&T contract that Apple would attempt to use here.

\footnotetext{
${ }^{65} \mathrm{Id}$.

${ }^{66}$ TracFone Wireless, Inc. v. Dixon, 475 F.Supp.2d 1236 (M.D. Fla. 2007).
} 
Presumably, iPhone owners could choose to breach their contracts with AT\&T, perhaps paying an early termination fee, ${ }^{67}$ and then unlock the phone in order to access another wireless network. Every individual who purchased a new iPhone entered into a software license agreement that, on its face, unequivocally prohibits circumvention of any access control. ${ }^{68}$ The relevant contract provision states that iPhone owners:

may not copy, decompile, reverse engineer, disassemble, attempt to derive the source code of, modify, or create derivative works of the iPhone Software, iPhone Software Updates, or any part thereof. Any attempt to do so is a violation of the rights of Apple and its licensors of the iPhone Software and iPhone Software Updates. $^{69}$

At the outset, Apple's argument for the enforceability of its iPhone contracts seems almost a given. The Uniform Commercial Code (UCC), which applies to contracts for the sale of goods, ${ }^{70}$ states that a contract may be formed "in any manner sufficient to show agreement."71 Apple's formal, written contracts with its customers very clearly meet the requirements for contract formation under the UCC.

In addition to its straight-forward contract argument, Apple has at its disposal a number of different policy arguments supporting its exclusive deal with AT\&T and its subsequent enforcement of the deal through the use of anticircumvention measures. These arguments are generally economic in nature and stand for the proposition that the level of consumer benefit generated by Apple's practices likely outweighs any concerns over technological controls and lack of competition. Perhaps the most obvious consumer benefit from the exclusive deal is the iPhone itself. In exchange for a five-year exclusive deal, AT\&T spent millions of dollars

\footnotetext{
${ }^{67}$ According to the contract, this fee would amount to $\$ 175$. See AT\&T Terms of Service agreement (available at http://www.apple.com/legal/iphone/us/terms/service_att.html).

${ }^{68}$ iPhone Terms of Service Agreement, http://www.apple.com/legal/iphone/us/terms/service_all.html\#iphonesla (last visited May 7, 2008).

${ }^{69} \mathrm{Id}$.

${ }^{70}$ U.C.C. $\S 2-102(2004)$.

${ }^{71}$ U.C.C. $\$ 2-204(2004)$.
} 
reworking its network in order to support the iPhone's innovative features, such as "visual voice mail."72 In addition to adding technological value, Apple's exclusive deal with AT\&T almost certainly helped Apple set a lower price for the iPhone. Indeed, it is common practice in the wireless market, for a handset manufacturer to use a wireless network as a way to subsidize production of handsets. ${ }^{73}$ Apple would therefore contend that its use of anticircumvention technology was reasonably necessary to enforce its agreement with AT\&T, and such restraints are permissible given the benefits that flow from the AT\&T agreement. If confronted with the argument that its behavior fuels anticompetitive behavior on the part of wireless networks, Apple could argue that this charge rings hollow, as the wireless industry is actually fairly competitive and wireless networks possess less power over handset manufacturers than is commonly thought. $^{74}$

\section{ii.) The DMCA Exemption Has Been Weakened by Tracfone}

Finally, Apple could argue that the strength of the 2006 DMCA exemption is lessened by Tracfone Wireless, Inc. v. Dixon, which arguably narrowed the scope of the DMCA exemption. ${ }^{75}$ In Tracfone, the court held that defendants who purchased mobile phones in bulk in order to unlock and later resell the phones were not entitled to the protection of the DMCA exemption because their conduct fell outside the scope of the exemption. ${ }^{76}$ Apple may try to use Tracfone to support the general proposition that the 2006 exemption is not ironclad and arguably should not apply in this case because the value of its application is outweighed by the contract principles at stake. While this may be a plausible argument, it is more likely that the court in TracFone

\footnotetext{
${ }^{72}$ Fred Vogelstein, The Untold Story: How the iPhone Blew Up the Wireless Industry, WIRED, Jan. 9, 2008, $\mathrm{http} / / / \mathrm{www} . w i r e d . c o m / g a d g e t s /$ wireless/magazine/16-02/ff_iphone.

${ }^{73} I d$.

${ }^{74}$ For a comprehensive study of competition among wireless networks that reaches such conclusions, see Robert W. Hahn, Robert E. Litan, and Hal J. Singer, The Economies of 'Wireless Net Neutrality, 3 J. COMPETITION L. \& ECON. 399.

${ }^{75}$ TracFone Wireless, Inc. v. Dixon, 475 F.Supp.2d 1236 (M.D. Fla. 2007).

${ }^{76} I d$. at 1238 .
} 
intended to limit application of the exemption under the particular facts of the case and not in any sort of general manner. ${ }^{77}$ Thus, Apple's argument that TracFone should somehow obviate concerns about the DMCA exemption's application to the iPhone is, at best, very thin.

\section{B. Arguments Against Apple's Use of Anticircumvention Technologies}

For reasons given above, Apple's argument that its contracts are valid seems fairly strong. Consumers are then left with two basic arguments. First, they may argue federal copyright law should preempt any state contract law Apple seeks to enforce. Second, if the state contract law is not preempted, consumers may still argue that the iPhone contracts should be declared void as a matter of public policy.

\section{i.) The iPhone Contracts May Be Preempted by Copyright Law}

Section 301 of the Copyright Act provides that all rights "within the general scope of copyright $\ldots$ are governed exclusively by [federal copyright law]. [N]o person is entitled to any such right or equivalent right in any such work under the common law or statutes of any State."78 The question is whether iPhone contracts would be preempted by federal copyright law. Although the plain language of Section 301 would seem to indicate that contracts, which fall under state law, are potentially subject to copyright preemption, this has not been the case in terms of practical jurisprudence. ${ }^{79}$ Indeed, it is often rather difficult to use Section 301 to preempt a contract that was otherwise enforceable under state law. ${ }^{80}$ On the other hand, some courts are more willing to entertain the possibility of preemption so long as the contractual

\footnotetext{
${ }^{77}$ The court's language indicates that the reason the DMCA exemption did not protect the defendants' actions was, quite simply, that the plain language of the exemption left such conduct open to liability. The court noted that unlocking handsets "for the purpose of reselling those handsets for a profit" clearly fell outside the scope of the exemption, which covers unlocking "for the sole purpose of lawfully connecting to a wireless telephone communication network." Id.

78 17 U.S.C. § 301(a) (2006).

${ }^{79}$ Raymond T. Nimmer, Breaking Barriers: The Relation Between Contract and Intellectual Property Law, 13 BERKELEY TECH. L. J. 827, 862 (1998).

${ }^{80} I d$.
} 
obligation is something that goes to the core of copyright law. ${ }^{81}$

Even though the possibility of copyright preemption is always lurking, it is less than likely that the iPhone contracts would be preempted here. One possible explanation for this result is that while courts will generally favor federal copyright law over copyright doctrine as articulated in state law, they are leery of second-guessing the nature of bargains entered into freely by private parties. $^{82}$ This explanation squares perfectly with Apple's likely response, which would be that iPhone purchasers have no reason to complain, as they received exactly what they bargained for. Since is unlikely that a Section 301 preemption argument will be of use to consumers, they must look for another legal doctrine in which to couch their claim.

\section{ii.) The iPhone Contracts May be Unenforceable as a Matter of Public Policy}

Assuming that the iPhone contracts are indeed valid contracts, and assuming that the contracts are not preempted by copyright law, the more pertinent question becomes whether these contracts may be declared void as a matter of public policy. According to the Restatement (Second) of Contracts, a contract is unenforceable for public policy reasons if either: "legislation provides that it is unenforceable or the interest in its enforcement is clearly outweighed in the circumstances by a public policy against the enforcement of such terms." 83

It may be argued that Apple has quite clearly deprived its customers of an explicit protection afforded to them by DMCA exemption. Congress feared an overbroad application of the DMCA's anticircumvention provisions in $\S 1201$, which is why they built in the triennial rulemaking procedure ${ }^{84}$ as a mechanism to apply the DMCA clearly, efficiently, and fairly. At

\footnotetext{
81 "If the promise amounts only to a promise to refrain from reproducing, performing, distributing or displaying the work, then the contract claim is preempted." Wrench, LLC v. Taco Bell Corp., 256 F.3d 446, 457 (6th Cir. 2001).

82 "The fact that contracts or contract terms are not subject to section 301(a) preemption reflects, in part, that the very idea of preemption does not readily apply to private conduct or transactional choices." Nimmer, supra note 79, at 862 .

${ }^{83}$ RESTATEMENT (SECOND) OF CONTRACTS $§ 178$ (1981).

${ }^{84} 17$ U.S.C. $\S 1201(\mathrm{a})(1)(\mathrm{C})(2006)$.
} 
the conclusion of the 2006 rulemaking procedure, the Librarian of Congress made it clear that the DMCA should not find liability for consumer mobile phone unlocking. ${ }^{85}$ In short, unlocking cell phones is perfectly legal conduct. Thus, when Apple famously "bricked" unlocked iPhones through its software update process, ${ }^{86}$ it was punishing its customers for engaging in lawful conduct, explicitly protected by copyright law. But the restraint of lawful activity is not the touchstone for contract invalidity. ${ }^{87}$ If this were in fact the state of the law, courts would be faced with the daunting task of voiding a wide range of useful contracts with provisions restraining otherwise lawful conduct.. The crucial question is not whether the iPhone contract restrains lawful conduct, but whether the policy goals at stake are so important as to justify the invalidation of the iPhone contracts. To address this question, it is necessary to look back at the policy supporting the 2006 exemption to the DMCA.

The key policy argument underlying the exemption is that companies who were using anticircumvention technologies in the context of the mobile phone market were doing so primarily as a means of securing business success. ${ }^{88}$ Or, to revisit the words of the Register of Copyrights, the decision by handset manufacturers to employ anticircumvention technologies was primarily a "business decision that has nothing whatsoever to do with the interests protected by copyright." ${ }^{\prime 9}$ The public policy argument is clear: concerns about competition are readily identifiable and any copyright justification is tenuous. The question then becomes to what extent iPhone owners will be able to present these policy concerns in a manner that clearly

\footnotetext{
${ }^{85}$ Exemption to Prohibition on Circumvention, supra note 41.

${ }^{86}$ See Hafner, supra note 12.

${ }^{87}$ One example of lawful conduct that is often restrained by contract is an exiting employee's ability to work for a competing company, which may be limited through a covenant not to compete. See, e.g., Paramount Termite Control Co., Inc v. Rector, 380 S.E.2d 922, 924 (Va. 1989) (holding that a coventant not to compete is lawful when it is: (1) no greater than necessary to protect its legitimate business interests; (2) not unduly harsh or oppressive; and (3) not against public policy.)

${ }_{88}$ Exemption to Prohibition on Circumvention, supra note 41.

${ }^{89} \mathrm{Id}$.
} 
demonstrates the need for a court to override the dominion of contract law in the particular instance. To answer this question, we will first look at the how consumers are likely to frame their policy argument and then consider how well this argument withstands the application of existing precedent.

\section{(a) Framing Consumers' Policy Argument}

Consumers may find it useful to appeal to conventional notions of private property rights in making their argument. The argument here is appealing in its simplicity: when a person purchases an iPhone, that person, as rightful owner of the phone, should generally be free to use that phone in any manner she sees fit. Put differently, under a conventional property rights framework, the manufacturer of that particular device should not be able to exercise much control, if any, once the sale of the phone is made. One analogy consumers might make is to the purchase of a car. For example, when one purchases a new Honda, one might become eligible for discounted service and maintenance provided at authorized Honda dealerships, but one is surely not obligated to service one's car exclusively at Honda dealers. Indeed, one can take the Honda to any number of mechanics or conduct maintenance at home. As a result, consumers feel a certain degree of freedom with respect to the goods they own, and a robust after-market for parts, repairs, and services has emerged in the automotive market. Consumers could thus argue that the same basic logic would help govern the mobile phone market more effectively.

This argument needs some polishing in order to make sense within the contours of property law generally and the $21^{\text {st }}$ century economy. The rights afforded by property law are not monolithic. Property law refers to property rights as consisting of a "bundle" of different rights. ${ }^{90}$ The question is: what rights does one acquire when one purchases a mobile phone such as the iPhone? Conversely, what rights should Apple, as manufacturer, retain after the phone is

\footnotetext{
${ }^{90}$ See J.E. Penner, The "Bundle of Rights" Picture of Property, 43 U.C.L.A. L. REV. 711 (1996).
} 
sold? The technological realities surrounding the iPhone add further wrinkles to the already complex, textured landscape of property law. Would an argument packaged in the rhetoric of private property aid consumers, or would Apple be correct in rejecting this argument as missing the point?

On the one hand, the logic behind the pro-consumer argument has its roots in traditional notions of private property rights, and it is quite appealing as a rhetorical tack. It is indeed tempting to see Apple's conduct regarding the iPhone as a flagrant interference with consumers' free use of their private property, one of the rights in the "bundle." On the other hand, Apple, like many in the media and communications markets, would argue that this conception of private property oversimplifies the exigencies of these particular markets. Apple would argue that in these markets, many of the goods that are sold will be "inherently technologically bound"91 and that such restraint is justifiable in light of marketplace realities. Most handset manufacturers need to create incentives for wireless networks to support their devices, because without the services provided by wireless networks, a handset by itself would be of little or no worth. For handset manufacturers, exclusive agreements, policed by anticircumvention technologies, is one of the best ways to create these incentives. Overall, Apple's argument seems stronger given that both the law and technology have evolved to support such technological restraints in certain cases. One should not dismiss, however, the rhetorical ammunition that consumers possess in the language of property rights.

At the onset, there is at least one factor that obviously weighs in favor of consumersthe fact that the policy at issue has been codified into law. ${ }^{92}$ It is generally easier to invalidate a

\footnotetext{
${ }^{91}$ Michael Madison, Law as Design: Objects, Concepts, and Digital Things, 56 CASE W. RES. L. ReV. 381, 393 (2005).

${ }^{92}$ The exemptions expressed in 71 Fed. Reg. 68472-01 have been codified at 37 CFR 201.40(b).
} 
contract as a matter of public policy when there is express legislation on point. ${ }^{93}$ This general rule might not apply to the current situation, as there is nothing in the plain language of the exemption itself that makes contracts that support the use of anticircumvention technologies unenforceable in this context. ${ }^{94}$ Apple, for its part, would likely try to argue that the ephemeral nature of the provision ${ }^{95}$ should make it a less persuasive source of authority. To some extent, Apple is correct. It is unlikely that the mere existence of the 2006 exemption will be dispositive of this issue, but, at the very least, consumers are benefited by the fact that the policy they are seeking to enforce has been enacted into law.

Perhaps the best way to assess the likelihood that consumers will prevail on their public policy argument is to compare the present situation to available precedent. Although there is a wide range of holdings that have invalidated contracts as a matter of public policy, this discussion will focus on two conflicting precedents, both involving the computer manufacturer, Gateway. ${ }^{96}$ The question in both cases is, as a matter of public policy, whether Gateway's "arbitration clause" 97 was a valid contract term. These cases are particularly helpful because they deal with "shrink-wrap" agreements in which the purchaser of a new electronic device was given a lengthy contract along with the purchase. ${ }^{98}$ Like the purchaser of a new iPhone, the consumers in these cases are likely to have accepted the goods in question without having read

\footnotetext{
${ }^{93}$ See ReSTATEMENT (SECOND) OF CONTRACTS $§ 178$ (1981).

${ }^{94}$ The exemption provided that the following should not constitute infringement under the DMCA: "[c]omputer programs in the form of firmware that enable wireless telephone handsets to connect to a wireless telephone communication network, when circumvention is accomplished for the sole purpose of lawfully connecting to a wireless telephone communication network." Exemption to Prohibition on Circumvention, supra note 41.

${ }^{95}$ The exemptions created through the rulemaking process last only for a period of three years, at which point they are considered for renewal. Exemption to Prohibition on Circumvention, supra note 41.

${ }^{96}$ See Hill v. Gateway 2000, Inc. 104 F. Supp. 2d 1332 (D. Kan. 2000) and Klocek v. Gateway, Inc., 105 F.3d 1147 (7th Cir. 1997).

${ }_{97}$ An arbitration clause is simply a clause contained within a contract stating that all disputes are to be resolved through private arbitration rather than in a court of law.

${ }^{98} I d$.
} 
most, if any, of the terms in the rather lengthy corresponding contract. ${ }^{99}$

\section{(b) Evaluating Consumers' Arguments in Light of Existing Precedent}

In Klocek v. Gateway, Inc., the Kansas District Court held that Gateway's arbitration clause was not enforceable as a matter of public policy. ${ }^{100}$ But in Hill v. Gateway 2000, Inc., the Seventh Circuit Court of Appeals ruled that the clause was enforceable. ${ }^{101}$ The outcomes in these two cases turns on whether the consumer in each case had "accepted" the terms of the contract by keeping the computer. In Klocek, the contract stated that the purchaser would be considered to have accepted the computer by keeping it for five days after the date of delivery. ${ }^{102}$ In Hill, however, the contract gave the purchaser 30 days to return the computer before acceptance was inferred. ${ }^{103}$ One explanation for the differing outcomes might be the fact that the purchaser in Hill was given more time to read and consider the terms of the contract before being bound to those terms. If this is true, it would likely support the claim that the iPhone Software License Agreement is unenforceable as a matter of public policy, as iPhone purchasers are deemed to have accepted the terms as soon as they use the phone. ${ }^{104}$ Thus, consumers may have a persuasive argument as to the procedural unfairness of the iPhone contracts because a substantial segment of iPhone purchasers will activate and use their phones before reading and considering all of the terms in the 17,000 word contract. ${ }^{105}$

Apple may respond by suggesting that iPhone purchasers should have been aware of the

\footnotetext{
${ }^{99}$ It is probably safe to assume that most iPhone purchasers did not, in fact, read the 17,000 words contained in Apple's iPhone contract. See David Kravets, iPhone Contract is Long and Legally Murky, WIRED, July 20, 2007, http://www.wired.com/gadgets/wireless/news/2007/07/iphone_contract?currentPage=all.

${ }^{100}$ Klocek, 104 F. Supp. 2d 1332.

${ }^{101}$ Hill, 105 F.3d 1147.

${ }^{102}$ Klocek, 104 F. Supp. 2d at 1335.

${ }^{103}$ Hill, 105 F.3d at 1148.

${ }^{104}$ Apple and Third Party Terms and Conditions,

http://www.apple.com/legal/iphone/us/terms/service_all.html\#iphonesla (last May 14, 2008) (Apple contract reads: "BY USING YOUR iPHONE, YOU ARE AGREEING TO BE BOUND BY THE TERMS OF THIS LICENSE.")

${ }^{105}$ Kravets, supra note 100.
} 
existence of the term preventing consumers from modifying the iPhone's software. A large number of products, particularly in the high-end electronics market, come with terms of use that restrain consumers' range of potential uses in some manner. ${ }^{106}$ Thus, it would be reasonable for iPhone purchasers to look to the terms of the contract to discover these limitations. Even if purchasers were not aware of this particular provision, Apple could argue every purchaser was at least aware of the existence of the exclusive agreement with AT\&T. The logic of this argument is that consumers' knowledge of the AT\&T deal somehow put them "on notice" of the fact that it was impermissible to modify the iPhone's software.

On the other hand, this logic might not be that persuasive. For instance, a consumer who, either in ignorance of the software agreement or in reliance on the 2006 DMCA exemption, decided to unlock her iPhone might be well aware of the AT\&T agreement but simply make a rational decision to breach the agreement and pay any resulting fees. The question then becomes whether a court would be willing to support consumer expectations about unlocking the iPhone, regardless of whether those expectations arose from either misunderstanding, ignorance, or from an explicit reliance on the 2006 exemption to the DMCA regarding mobile phones.

As discussed earlier, the rulemaking exemptions to the DMCA have a peculiar importance in copyright law, supplying the recently-enacted DMCA with its own version of the "fair use" doctrine. ${ }^{107}$ In particular, the 2006 mobile phone exemption provided consumers with a clear expectation that unlocking a mobile phone for the purpose of lawfully accessing a different wireless network would not render them liable for copyright infringement. ${ }^{108}$ Even

\footnotetext{
${ }^{106}$ See, e.g., Microsoft Windows XP Home Edition (Retail) End-User License Agreement, http://www.microsoft.com/windowsxp/home/eula.mspx (last visited May 14, 2008) (Microsoft's agreement limits, among other things, the number of computers on which the Windows XP software may be used and limits the ability to alter or modifiy or alter certain aspects of the software itself).

107 17 U.S.C. $\S 1201$ (a)(1)(B) (2006).

${ }^{108}$ Exemption to Prohibition on Circumvention, supra note 41.
} 
though it is perfectly lawful to unlock a mobile phone, a contract does not fail for public policy reasons simply because it exercises a restraint on lawful conduct. ${ }^{109}$ Consumers' likelihood of success thus depends on the perceived strength of the policy in question.

On one hand, unlike the arbitration clauses in the Gateway cases that required consumers to waive their right to file a lawsuit against Gateway, the Software License Agreement arguably involves a less significant abrogation of rights. Put differently, limiting one's right to bring a civil suit is more likely to offend public policy than limiting one's ability to modify the software on one's mobile phone. A court that adopts this view will be more likely to favor general contract principles at the expense of the public policy supporting mobile phone unlocking.

On the other hand, unlike the plaintiffs in the Gateway cases, iPhone purchasers who unlocked their phones can look to an explicit, affirmative legal protection to support their argument. Although the right to bring a civil action is one that is afforded protection under the laws of each state, ${ }^{110}$ this kind of legal protection is distinguishable from the protection governing mobile phone unlocking. The right to sue may be characterized as a passive, extant right, belonging generally to any person who can state a cause of action. The right to unlock a mobile phone, however, is a right that stems from a particular rulemaking process, designed to address a particular problem confronting consumers. At bottom, the 2006 DMCA exemption hoped to address consumer concerns about lack of freedom with respect to use of their mobile phones and lack of competition in the mobile phone industry. Any contract that abridges or limits the 2006 exemption can be seen as thwarting the important public policies behind the exemption. Because the anticircumvention provisions in the iPhone Software License Agreement plainly deny consumers the protection given to them by the 2006 DMCA exemption,

\footnotetext{
${ }^{109}$ See Wrench, LLC v. Taco Bell Corp., 256 F.3d 446, 457 (6th Cir. 2001).

${ }^{110}$ Fed R.Civ. P. 17(b).
} 
a court may choose to declare these provisions void as a matter of public policy.

\section{Treatment of the iPhone Abroad}

Until this point, the discussion has focused exclusively on the iPhone as sold to consumers in the United States and as it relates to American copyright law. Before reaching any conclusions as to how the iPhone should be treated domestically, it will be useful to examine briefly how the iPhone has been treated abroad. As of January 2008, the iPhone was available for purchase in the United States, the United Kingdom, Germany, and France; and there is talk of a Japanese release within the year. ${ }^{111}$ As it did in the United States, Apple sought exclusive arrangements as it moved abroad. In the United Kingdom, Apple enjoys an exclusive deal with mobile phone operator $\mathrm{O} 2 .^{112}$ Matters have been somewhat more complex regarding iPhone sales in Germany and France.

In Germany, T-Mobile, Deutsche Telekom's mobile phone arm, was initially awarded an exclusive deal with Apple. ${ }^{113}$ T-Mobile's competitor, Vodafone, challenged this arrangement as illegal and anticompetitive and eventually was granted an injunction against T-Mobile, which prohibited them from selling only a locked version of the iPhone. ${ }^{114}$ Displeased at the prospect of selling unlocked phones, T-Mobile challenged the court order and ultimately won, reserving for itself the right to sell locked iPhones exclusively. ${ }^{115}$

In France, Apple once again entered into an exclusive deal with a leading telecom

\footnotetext{
${ }^{111}$ Elizabeth Woyke, Apple's Fight in Japan, FORBES.COM, Jan. 15, 2008, http://www.forbes.com/2008/01/15/iphone-apple-japan-tech-wireless-cx_ew_0115appljap.html.

${ }^{112}$ O2 Wins iPhone Contract in the UK, BBC NEWS, Sept. 18, 2007, http://news.bbc.co.uk/2/hi/business/7000370.stm.

${ }^{113}$ D. Telekom's Mobile Unit Clinches iPhone Deal: Paper, REUTERs, July 3, 2007, http://www.reuters.com/article/technologyNews/idUSL0383260920070703.

${ }^{114}$ Gerrit Wiesmann, Vodafone Unit Wins Court Injunction. FIN. TIMES, Nov. 20, 2007, http://www.ft.com/cms/s/0/8e189682-970c-11dc-b2da-0000779fd2ac.html.

${ }^{115}$ David Meyer, T-Mobile Germany Stops Selling Unlocked iPhones. CNET NEWS.COM, Dec. 4, 2007 , http://www.news.com/T-Mobile-Germany-stops-selling-unlocked-iPhones/2100-1039_3-

6221306.html?tag=st.ref.goo.
} 
company, but this agreement has some noticeable differences. ${ }^{116}$ France Télécom's wireless unit, Orange, was awarded the exclusive right to sell the iPhone but, in order to comply with French consumer law, ${ }^{117}$ Orange agreed to sell both a locked version that would work only on the Orange network and an unlocked version that consumers could use on the network of their choice. $^{118}$ In exchange for the freedom that comes with an unlocked iPhone, consumers agree to pay a somewhat higher ticket price. ${ }^{119}$ Interestingly, the locked version of the iPhone has actually outsold the unlocked version, accounting for roughly $95 \%$ of iPhone sales during the first month. ${ }^{120}$

At some level, the situation in the United States is similar to the situation in France. In both countries, Apple's exclusive deal with its respective wireless provider created the risk that Apple would run afoul of that country's laws. While there are obviously some distinctions between the French law in question and the 2006 exemption to the DMCA (the former is a consumer law, while the latter is a copyright law), Apple can nonetheless look to France as a model for how it should treat the iPhone in the United States. One option is quite simply for Apple and AT\&T to imitate the Apple/Orange agreement and sell both locked and unlocked iPhones, charging a premium for unlocked phones. This could lead to a win-win for both consumers and for Apple. On one end, consumers would have a greater degree of freedom and would be able to enjoy the protection of the 2006 DMCA exemption. And, on the other end, Apple would be able to offset any lost revenues by simply charging more for unlocked iPhones.

\footnotetext{
${ }^{116}$ Kevin J. O’Brien, Apple Chooses Orange as iPhone Operator in France, InT'L HeRALD TRIB.. Oct. 16, 2007, http://www.iht.com/articles/2007/10/16/business/apple.php.

${ }^{117}$ Law. No. 293 of Nov. 17, 1998, Journal Officiel de la République Française [J.O.] [Official Gazette of France], Dec. 18,1998, p. 19132.

${ }^{118}$ O'Brien, supra note 118.

${ }^{119}$ W. David Gardner, France's Orange Debuts iPhone for a Low Standalone Price, INFORMATIONWEEK, Nov. 28, 2007, http://www.informationweek.com/news/showArticle.jhtml?articleID=204300465.

${ }^{120}$ Jonny Evans, Orange France Sells 70,000 iPhones in First Month, COMPUTERWORLD, Jan. 7, 2008, http://www.computerworld.com/action/article.do?command=viewArticleBasic\&articleId=9055882.
} 
Indeed, think of the value Apple might have captured if they had been able to charge consumers a significant premium for each one of the estimated 1.7 million unlocked phones in the United States. ${ }^{121}$

\section{Conclusion}

To be sure, Apple's use of anticircumvention technologies and software updates in connection with its iPhone has generated something of a controversy. Consumers are understandably frustrated at the prospect of a locked — or, worse yet — bricked iPhone. This frustration has firm legal roots in the 2006 mobile phone exemption to the DMCA, which declares that mobile phone unlocking is a lawful activity. Apple, for its part, is rightly concerned about enforcing the boundaries of its exclusive deal with AT\&T. In the current mobile phone market, exclusive deals with wireless providers provide a critical subsidy that handset manufacturers have a hard time resisting. Is it possible to reconcile these tensions?

Consumers can go forward with a lawsuit against Apple, arguing, inter alia, that the terms in the iPhone contract prohibiting the modification of iPhone software should either be preempted by copyright law, particularly the 2006 exemption, or that such terms should be invalidated as a matter of public policy. For reasons mentioned above, consumers are likely to have more success with their public policy argument. A victory for consumers would be a victory for the policy behind the 2006 exemption and create clearer expectations, not only for Apple and iPhone owners, but for all market participants.

From the standpoint of copyright law and consumer protection alike, a victory for consumers is clearly the best result. But what of the contract law principles and economic efficiency interests that Apple would likely raise in its defense? There are good legal reasons to enforce the bargains of private parties, and there are also good policy reasons to allow market

\footnotetext{
${ }^{121}$ Kharif, supra note 15.
} 
actors such as wireless networks and handset manufacturers to come up with their own, efficiency-promoting arrangements. The question becomes to what extent these goals are upheld when they are placed in conflict with the aforementioned copyright and consumer freedom goals. Perhaps the best answer to this question will involve a balancing of these interests.

First, Apple can achieve its efficiency goal, while at the same time respecting the 2006 DMCA exemption, by following France's lead and selling both locked and unlocked versions of the iPhone at different price points. This arrangement would allow Apple to avoid any losses that result from selling an unlocked iPhone by simply charging more. Further, by agreeing in advance with AT\&T to share this additional revenue, Apple could create a built-in incentive for AT\&T to invest in additional features and enhanced network capabilities. Although consumers would have to pay more for an unlocked iPhone, they would not be blatantly denied the protection of the 2006 exemption. Rather, consumers would simply have to make a choice. Those who wanted an unlocked phone would simply be expected to pay more in a free market for that added value that comes with an unlocked phone. Similarly, consumers who simply wanted an iPhone and cared little about unlocking capabilities would be able to pay the lower price, subsidized by the exclusive AT\&T deal.

Second, the contract principles in question are not completely jeopardized by the prospect of unlocked iPhones. For instance, Apple currently refuses to honor unlocked phones under its warranty. ${ }^{122}$ This is most likely a reasonable restriction, and, unlike an outright ban on unlocking, it would not be outweighed by countervailing copyright law principles. If Apple is still worried about servicing unlocked phones, which may be more susceptible to viruses and other third-party damage, they could simply provide two different warranties - a more complete one for locked phones and a more limited one for unlocked phones. This approach is efficient

\footnotetext{
${ }^{122}$ See Hafner, supra note 12.
} 
because it leaves the decision with consumers, allowing them to take a calculated risk when they purchase an unlocked iPhone.

Finally, in the absence of a judicial opinion or legislative change requiring Apple to sell unlocked iPhones, or at the very least, allow consumers to unlock iPhones themselves, Apple may have an incentive to do take this course of action on its own. If Apple is to remain competitive in the evolving mobile phone market, it may have to respond to a consumer outcry and use open platforms. ${ }^{123}$ If this trend persists, eventually applications will work on any device and over any network. It is still an open question whether the prediction is correct that the wireless market will one day posses the "flexibility and functionality of the Internet." ${ }^{124}$ If this is the direction in which the market is headed, Apple may simply have no choice but to unlock the iPhone.

\footnotetext{
${ }^{123}$ This market solution is already underway, as Google has announced its new mobile phone software, Andriod, and the "Open Handset Alliance." Google's recent announcement has drawn support from FCC chairman, Kevin Martin. See Marguerite Reardon, FCC Chairman Supports Google's Open Handset Alliance, CNET NEWS.COM, Nov. 6, 2007, http://www.news.com/8301-10784_3-9812061-7.html.

${ }^{124}$ Fred Vogelstein, The Untold Story: How the iPhone Blew Up the Wireless Industry, WIRED, Jan. 9, 2008, http://www.wired.com/gadgets/wireless/magazine/16-02/ff_iphone.
} 